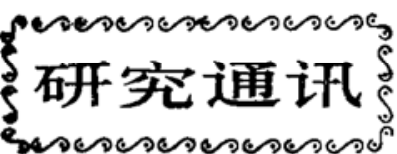

\title{
直流磁控浌射一冷凝一原位加压制备 纳米固体钿和氮化二钿*
}

纳米固体材料是由具有量子表面效应和 体积效应的超微粒子构成的块状固体材料. 是近年来出现的一个新的非常活䀓的领 域. 本文介绍采用直流磁控浌射一冷凝一原位加 压制备纳米固体钼和氮化二钼的部分实验结 果.

材料制备是在自行研制的 IAC-1 型纳 米固体材料制备设备上进行的，为辉光放电 一冷凝一原位加压方法, 包括: 直流/射频磁 控(反应)溅射、电阻加热辉光等离子体反应、 电阻加热两极溅射一冷凝一原位加压等项功 能. 其优点在于: 不受坩锅影响, 可制备复 杂组份材料、导体、半导体、绝缘体及各种气 体(如氧、氮等)的反应生成物等. 在制备纳 米固体钼和氮化二钼时, 用直流磁控(反应) 贼射一冷凝一原位加压功能, 采用纯钼靶 (3N). 先将真空室抽真空至 $4 \times 10^{-4} \mathrm{~Pa}$ 后, 充人循环气流. 制备纳米固体钼时, 充高纯 氞至 $0.5 \mathrm{~Pa}$, 加直流 $0.4 \mathrm{kV}, 2 \mathrm{~A}$, 真空室上部 冷阱加液氮冷却, 待冷阱接收到一定量的超 微粒子后, 停止溅射, 再抽真空至 $4 \times 10^{-4} \mathrm{~Pa}$. 用刮料器取下超微粒子送至原位加压装置中
在室温下加压至 $1.5 \mathrm{GPa}$ 成形. 样品直径为 $\phi 8 \mathrm{~mm}$. 溅射 $20 \mathrm{~min}$ 得圆片状样品重 137 $\mathrm{mg}$, 称重法测得样品比重为 $7 \mathrm{~g} / \mathrm{cm}^{3}$, 约为 常规金属钼的 $69 \%$. 样品平均粒度为 $8 \mathrm{~nm}$, 且较均匀, 为体心立方结构. 当充人高纯氧 气至 $0.2 \mathrm{~Pa}$, 再充人高纯氮至 $0.5 \mathrm{~Pa}$, 所得 样品为面心立方的氮化二钼, 平均粒为也为 $8 \mathrm{~nm}$. 显微硬度测试结果为: 纳米固体钼的 $H_{\mathrm{v}}=824 \mathrm{~kg} / \mathrm{mm}^{2}$, 为常规金属钼的 3 倍, 而 纳米固体氮化二钼的 $H_{\mathrm{v}}$ 为 $1850 \mathrm{~kg} / \mathrm{mm}^{2}$. 结果表明, 对于这种未烧结状态的纳米固体 钼, 在 $8 \mathrm{~nm}$ 的平均粒度时, 趋势上显微硬度 仍服从正常 Hall-Petch 关系.

采用这种方法, 获得的纳米固体粒度比 较均匀. 因为在靶表面, 浌射或蒸发条件比 较一致. 而在通人氮气后, 靶表面被等离子 体活化, 践射出来的物质表面也被活化,氮分 子也被离化,所以只要条件合适,很易形成氮 化物. 这就是我们制得粒度比较均匀的纳米 固体钼和氮化二钼的原因.

\section{朱 勇 秦 勇} （中国科学院固体物理研究所，合肥230031）

*国家自然科学基金资助项目.

\section{$\mathrm{C}_{60}$ 与卤代卡宾的气相离子-分子反应}

足球状全碳烯 $\mathrm{C}_{60}$ 具有丰富的化学性 质, 可以做为活泼的自由基捕捉试剂 ${ }^{[1]}$, 在 质谱常规化学电离源内气相 $\mathrm{C}_{60}$ 可与 $\mathrm{CCl}_{4}$, $\mathrm{CHCl}_{3}, \mathrm{CH}_{2} \mathrm{Cl}_{2}$ 和 $\mathrm{CHBr}_{3}$ 等产生的碎片发 生化学反应, 生成了 $\left[\mathrm{C}_{60} \mathrm{CX}_{2}\right]^{+}$等多种气相
衍生物离子.

单独引人 $\mathrm{CCl}_{4}$ 的离子源内存在着 $\mathrm{CCl}_{3}^{+}(m / z 117,100 \%), \mathrm{CCl}_{2}^{+}(m / z 82,22 \%)$, $\mathrm{CCl}^{+}(m / z 47,24 \%)$ 和 $\mathrm{Cl}^{+}(m / z 35,14 \%)$ 阳离子、多种阴离子及 $\mathrm{CCl}_{3}, \mathrm{CCl}_{2}, \mathrm{Cl}$ 等自 